\title{
COLLECTIVE "CONTRACTS" OR INDIVIDUAL STATUS? EMPLOYMENT UNDER MANAGEMENT-UNION AGREEMENTS
}

\author{
ALEXANDER SZAKATS*
}

In the following article Doctor Szakats discusses the nature of collective agreements in Great Britain, Canada, the United States, Australia and New Zealand. With particular reference to New Zealand, Doctor Szakats examines the character and binding force of collective agreements and discusses whether "statute" or "contract" is the basis of employment for individual workers.

\section{FORMS OF COLLECTIVE BARGAINING: FREE AND GUIDED}

Collective bargaining has been recognized and practised in most industrialized countries as the normal method of settling disputes between the two sides of industry and as the principal process of negotiating wages. A collective agreement resulting from such bargaining accordingly signifies a twofold achievement: first, it constitutes a treaty between a trade union and an employer or an employers' organization whereby the social partners ${ }^{1}$ express their intention to maintain peaceful industrial relations, and delimit their respective rights and duties; second, it lays down the rates of pay, conditions of work and other terms to be incorporated in the individual contracts of employment. ${ }^{2}$ Thus, besides what may be called strictly industrial relations issues in the sense that they affect the power of the parties, the collective agreement between management and union contains many issues directly referring to the position of the worker as a singular employee under a contract with a particular employer. These individual matters may be called collective only in the sense that they touch all the workers employed in the industry covered by the collective agreement but their ultimate purpose and effect is delineating the perimeter, and predetermining the substance, of the employment relationship. ${ }^{3}$

Attention will be focused in this article not on the process of bargaining but on the effect of the written instruments ${ }^{4}$ in which it culminates. Nevertheless, it should be noted at the outset that bargaining methods and procedures vary considerably in different countries and the diverse features may contribute to determining the true character and legal binding force of a particular instrument.

It needs to be considered at this juncture whether the term "bargaining" means only voluntary bipartite negotiation, or whether it also includes the process of mediation, conciliation and arbitration. ${ }^{5}$ The

- Dr.Iur., Dr.Pol. (Budapest), LL.B. (N.Z.), Professor of Law, University of Otago, Dunedin, N.Z., Associate of the Industrial Relations Centre, Victoria Univeristy of Wellington, Barrister and Solicitor of the Supreme Court of New Zealand.

1 This expression is used extensively in Western Europe to denote organized management and organized labour in their various relationships: see F. J. L Young. New Zealand Industrial Relations-Retrospects and Prospect, a paper delivered at the ILO/NORAD Industrial Relations Symposium for Asian Countries held in Manila, August 26September 6, 1975, published as an article in (1976) New Zealand Journal of Industrial Relations, 3.

2 See O. Kahn-Freund, Labour and the Law, (London, 1972) at 124-164.

3 A. Szakats, Introduction to the Law of Employment, (Wellington, 1975) paras. 9, 44 and passim; also Szakats, Legal and Social Problems of Employer-Employee Relationship, (1971) 2 Otago L.R. 313 at 320.

- "Instrument", "collective instrument" or "industrial instrument" are terms used to denote besides collective agreements also decisions, awards and rulings by an arbitrator or an arbitration body vested with decision making power.

$s$ "Meditation" and "conciliation" are frequently used as synonyms for the same process but in some countries 
introduction of a neutral person or body of persons creates a tripartite framework for the purpose of assisting to reach a compromise. But at the same time it derogates from the true voluntariness of the coming to terms by the two opposing sides. The third party invariably exerts a moral pressure-after all that is the reason for his involvement-in the form of skilful guidance and persuasion by strongly underlining the potential adverse economic and social consequences of a refusal to agree. Consequently, the intervention of the third party as a go-between narrows down considerably, but does not entirely remove, the elbowroom for adamant arguments and counter-arguments. The acceptance of any proposed solution, not withstanding the enervating effect of the specially induced compromise climate, depends on the parties to the dispute as they are in no way debarred from rejecting it, if in their view it is unfavourable to them; on the other hand, concurrence to a suggested settlement should be regarded as representing their considered opinion and expressed will. Thus, the process of bargaining, though guided by the third party, is still the principal method of reaching the ultimate compact, and the character of the instrument embodying it remains that of an agreement in the true meaning of the word.

Where the arbitration is compulsory in the sense that the parties must accept the decision of the arbitrator as binding and final, the element of free bargaining largely disappears. The third party, the arbitrator, in such a case does not merely advise, suggest and persuade but has the power to superimpose his decision against either of the parties' will. The procedure of arriving at the award hardly can be described as negotiation, rather it is in the form of a judicial or quasijudicial hearing. The parties may make submission and present arguments but they cannot reject the arbitral determination. ${ }^{6}$

Can such an award be equated with a collective agreement? Its effect as far as the parties, are concerned is very much the same. A collective agreement however, in some countries may be "extended" by administrative decree beyond the bargaining parties and thereby it loses its character as a voluntary settlement. What is then the real meaning of "bargaining collectively", and what is the effect of the resulting instrument, whether agreement or award, on the social partners, on the workers in the industry and on outsiders?

To find at least some of the answers the overall problem should be dissected to its components and a number of questions stated:

(1) Are collective agreements necessarily always freely negotiated bilateral settlements achieved through birpartite bargaining, or do they also include tripartite arrangements?

(2) Do collective agreements constitute legally enforceable contracts or are they mere extralegal conventions, voluntarily observed, subject only to economic and social sanctions?

(3) If the settlement takes the form of an award superimposed by arbitration, does the instrument have the same effect as a collective agreement, or by its very nature is it judicially enforceable?

are given a separate meaning. "Arbitration" again may be applied in the same sense, more frequently; however, it denotes hearing by a person or body with power to make binding decisions; in New Zealand all these terms have a statutorily defined distinct meaning.

- See A. Szakats, Trade Unions and the Law, (Wellington, 1968) 35-40, 78-79, 85-86.

: See A. Brun, "Collective Agreements in France", in Labour Relations and the Law, ed. O. Kahn-Freund, (London, 1965) 78; see infra, Parts II and III. 
(4) Can a collective agreement or an arbitral award be extended beyond the original parties to further persons and organizations regardless of, or even contrary to, their will, and thereby transform its bilateral (and, in the case of agreement, volitional) character into an erga omnes coercive regulatory norm?

Further questions arise with reference to the secondary aspects of a collective instrument which can also be set out seriatim:

(1) Does the instrument (if it is binding at all) bind individual workers and individual employers not direct parties to it in the same way as the parties to the bipartite or tripartite procedure?

(2) Are the relevant terms of the instrument incorporated in the actual contracts of employment as a matter of legal compulsion or as freely adhered "crystallized" custom"?

(3) Hence, do the employer and the worker have legal power ${ }^{9}$ to make their own bargain and agree on different terms?

(4) If they must not deviate from the terms of the collective instrument, can it be asserted that such circumstance, coupled with other mandatory conditions imposed on the employment relationship by legislation, completely abrogates all criteria of contractual freedom?

(5) Consequently, when taking employment does the worker enter into a standardized contract, or does he join a specified class of persons covered by the industrial instrument, whereby all his rights and obligations derive from the fact that he belongs to that class?

These questions are intended to be examined briefly in the context of several industrialized countries. Particular attention will be given to collective instruments in New Zealand, as they present a noteworthy range of voluntary bipartite agreements, conciliated tripartite agreements and quasi-judicial awards which show certain unique features in respect of their binding force. Finally, the impact of the collective instrument on the employment relationship needs to be considered: has status superseded contract?; has the employment become a matter of status, or is it still based essentially on contract?

\section{A BRIEF OVERVIEW OF COLLECTIVE AGREEMENTS IN FOUR COUNTRIES}

\section{A. The Scope of Inquiry}

In examining how the questions set out in the introductory part of this article are answered by different industrial relations systems it is intended to make a brief survey of the character and binding force of collective agreements in four advanced industrialized countries. Regrettably, the operative word is "brief", as within the limited confines of the present essay all the complex ramifications which are essential to a full understanding of the respective systems cannot be explored in detail, and by necessity the exposition will be a mere overview with emphasis on some salient points. ${ }^{10}$ The purpose of the examination followed by a scrutiny of the effect of collective instruments in New Zealand is to lead

8 This expression is used by O. Kahn-Freund in Labour and the Law, supra, n. 2 at 141.

The employer may have economic power to deviate but it is counterbalanced by the union's economic power; deviation in favour of the employee usually is allowed.

10 For full details see the sources quoted later in this part. 
up to the final argument as to whether or not status has superseded contract.

The chosen countries, Britain, the United States, Canada, Australia and New Zealand all belong to the Anglo-American legal family, but despite the shared common law heritage their labour law has developed in quite divergent directions. In the field of labour relations and its legal framework, it has been pointed out that the importance of the underlying common law or civil law tradition should not be exaggerated. ${ }^{11} \mathrm{As}$ examples for this proposition four leading European industrial nations can be quoted: France, West Germany, Italy and Sweden. The first three are members of the Romano-Germanic or civil law system, while Sweden, though its substantive law retained original Nordic elements, has also been greatly influenced by Romanist scholarship.12 Notwithstanding similarities in their legal infrastructure, their industrial relations systems show considerable differences, and in certain respects are more akin to common law jurisdictions than to one another.

Moreover, it must be borne in mind that Britain's membership in the European Economic Community has brought her closer to the continental law system, ${ }^{13}$ and no doubt future harmonization efforts will further enhance this trend. As a result the old-established common law-civil law dichotomy can be abandoned, at least in the context of labour relations law. In any case every country has its own industrial relations system developed more under the influence of political and economic factors than juristic ideas, and it must be repeated that legal traditions or adherence to transnational organizations play a mere secondary role in determining the effect and binding force of collective instruments.

\section{B. Great Britain}

Under the now repealed Industrial Relations Act 1971 every written collective agreement was statutorily presumed to have been a legally enforceable contract, unless the parties expressed a contrary intention in the instrument itself. They could agree that the non-enforceability be restricted to certain specified provisions and the presumption in such cases remained applicable to the rest of the agreement only. ${ }^{14}$ The Trade Union and Labour Relations Act 1974 reversed the presumption. A collective agreement now shall be conclusively presumed to have been intended to be a legally enforceable contract only if

(a) it is in writing, and

(b) contains an express provision of the parties' intention to that effect.

Unless these two conditions are satisfied, the presumption of the intention not to create a legally enforceable contract will arise. ${ }^{15}$ The parties, as in the previous statute, may select specified parts, with the

"Kahn.Freund, "Introduction", Labour Relations and the Law, supra, n. 7 at 3.

12 R. David and J. E. C. Brierley, Major Legal Systems in the World Today (London, 1968) 41; although it would be most interesting the confines of the present article preclude even a brief analysis of these four industrial relations systems mentioned.

13 See the Treaty of Rome, esp. Art. 177; H. P. Bulmer Ltd. and Another v. J. Bollinger S.A. and Others [1974] 2 All E.R. 1226 (C.A.); . . . "when we come to matters with a European element, the treaty is like an incoming tide. It flows into the estuaries and up the rivers. It cannot be held back ..." per Lord Denning M.R. 1231; as to the effect on English Law not concerning E.E.C. matters see Schorsch Meier v. Hennig [1975] 1 All E.R. 152 (C.A.); Miliangos v. George Frank (Textiles) Ltd. [1975] 2 W.L.R. 758 (H.L.); as to Art. 48, free movement of workers, Van Duyn v. Home Office [1975] 2 W.L.R. 760 (Eur. Court of Justice).

14 Industrial Relations Act 1971, 8. 34 (repealed).

15 Trade Union and Labour Relations Act 1974, 8. 18(1) and (2). 
intention of legal enforceability clearly stated, and the remainder will be presumed to be unenforceable. The unenforceable portions of the written instrument, nevertheless, may be referred to for the purpose of interpreting the enforceable provisions. ${ }^{16}$

It is important to note that the statutory presumption applies only to collective agreements made before December 1,1971 and after the commencement of the relevant section of the present Act, September 16, 1974.17 Agreements made between these two dates under the former statute, if lacking any express provision to the contrary, could be enforced before the National Industrial Relations Court, ${ }^{18}$ but if no proceedings were started before the second date, it appears that such right is lost. The Trade Union and Labour Relations Act provides that: ${ }^{19}$

[W] here any right, obligation or liability has accrued or been incurred under any provision of the 1971 Act ... before the repeal of that provision by this Act takes effect, but no proceedings have been commenced in any court or tribunal to enforce that right, obligation or liability, no proceedings to enforce it . . . shall be commenced in any court or tribunal after that repeal takes effect.

Commencement of proceedings indicates that the parties' presumed intention of enforceability represents their real intention. With the abolition of the National Industrial Relations Court its special jurisdiction has ceased and pending cases are being transferred to the courts of general jurisdiction. ${ }^{20}$ Where enforceability has been expressly stipulated in a still extant collective agreement made between the relevant dates, the party seeking enforcement does not rely on a now reversed statutory presumption but on a contractual right, and may commence action before a competent court of law at any time. ${ }^{21}$

The legal status of collective agreements before the introduction of the statutory presumption in either way was described as an "area of acute controversy."22 Statute law did not contain any provision in this respect. Judicial decisions likewise provided no sure guidance. As recently as 1969 the High Court held in Ford Motor Co. v. Amalgamated Union of Engineering and Foundry Workers ${ }^{23}$ that the collective agreement between the parties did not constitute an enforceable contract, but this decision cannot be regarded as laying down a general rule. The Court found that the relevant terms disclosed no intention of creating a legally enforceable contract. Earlier cases quoted in the judgment also turned on their own facts, and none of them could be relied on as a clear authority on principle. ${ }^{24}$

The prevailing view in the late nineteen sixties appeared to be that collective agreements were not binding contracts, and the parties

10 Id. 8. 18(3).

17 Id. 8. $18(1)$.

18 Industrial Relations Act, 8. 129 (repealed); the Industrial Court had exclusive jurisdiction.

19 Trade Unions and Labour Relations Act, 8. 23(3).

20 Id. 83. 1, 21 and 22; the Interpretation Act 1889, 8. 38(2) would otherwise prevent a repealing enactment to affect any right, privilege, obligation or liability accrued or incurred under the repealed enactment, but for the express prohibition in $8.23(3)$ of the Trade Union and Labour Relations Act as above.

21 See B. A. Hepple and P. O'Higgins, Encyclopedia of Labour Relations Law, (London, 1972) (loose leaf with current supplements), 2-1270; see also R. W. Rideout, The Place of Legislation in Labour Law (1974) 27 Cur. Legal Problems 212

22 Supra, n. 2 at 129.

23 [1969] 2 All E.R. 481 (Q.B.D., Geoffrey Lane J.).

24 East London Bakers Union v. Goldstein (1904) The Times, June 9; Smithies v. National Assn. of Operative Plasterers [1909] 1 K.B. 310; Holland v. London Society of Compositors [1924] 40 T.L.R. 440; Bradford Dyers" Assn. Ltd. v. National Union of Textile Workers (1926) The Times, July 24; Young v. Canadian Northern Railway Co. [1931] A.C. 83; Hynes v. Conlon (1939) Ir. Jur. Rep. 49; National Coal Board v. Galley [1958] 1 All E.R. 91; see Selwyn, Collective Agreements and the Law (1969) 32 M.L.R. 377. 
themselves preferred to rely on economic and social, rather than legal, sanctions for its enforcement. ${ }^{25}$

At this juncture the question arises: even though a collective agreement can at present be made expressly enforceable, what terms may be directly enforced by and against the primary parties, the employers and the trade unions? Obviously, the majority of the clauses are intended to have a normative effect for the purpose of incorporating them in the individual employment contracts, ${ }^{26}$ while others by their very character regulate merely the relations of the social partners. The normative clauses, if expressly or tacitly incorporated in an actual service contract, can be enforced quite independently of the collective agreement. This secondary enforcement does not depend on whether the parties are legally bound to abide by the norms regulating conditions of employment, or merely observe them as a matter of convenience, "crystallized custom,"27 or economic prudence. If there is primary enforceability, then the normative terms must not be deviated from, unless in favour of the employee, and the union itself may bring an action for violation against the employer or employers' organization, the party to the collective agreement.

With respect to clauses that concern the social partners themselves, frequently referred to as procedure agreements, the prevailing view in the past was that they were not contractual, and they should not even be made into contractual undertakings either in the primary or the secondary sense. ${ }^{28}$ The essence of a "no-strike, no lock-out" clause-the "peace obligation" is that certain procedures aiming at settlement should be exhausted before resorting to direct action. Such issues primarily relate to union, not individual, matters, and they may be seen not only as invidious but otiose in the context of service contracts. It can, of course, be asserted that no strike is possible without the workers actually withdrawing their labour, but whether or not by obeying a union decision they would commit a breach of their contract is quite a different question. ${ }^{29}$

The present statute provides that terms in a collective agreement which prohibit or restrict the right of workers to engage in a strike or

${ }^{25}$ Kahn-Freund, "Legal Framework" in The System of Industrial Relations in Great Britain, ed. A. Flanders and H. A. Clegg, (Oxford, 1964) 56;-" "Report on the Legal Status of Collective Bargaining and Collective Non-contrgetural Nature of Collective Agreements in Great Britain and in Eire" in Labour Relations and the Law, ed. Kahn-Freund, (London, 1963) 21 and at 40; Kahn-Freund, Labour and the Law (London, 1972) $129 \mathrm{et}$ seq; the Donovan Report, Royal Commission ofn Trade Unions and Employers' Associations, (Cmnd. 3623, 1968), paras. 470-471; C. Grunfeld, Modern Trade Union Law, (London, 1966) 219, Citrine's Trade Union Law. 3rd ed. of M. A. Hickling, (London, 1967) 136; R. W. Rideput, Principles of Labour Law. (London, 1972) 70, 75; Trade Unions and the Law. (London, 1973) 159; K. W. Wedderburn and P. L. Davies, Employment Grievances and Dispute Procedures in Britain, (Berkley, 1969) 72-74; K. W. Wedderburn, The Worker and the Law. (Penguin, 1972) 105-111, (with some hesitation); W. M. Cooper and J. C. Wood, Outlines of Industrial Law, 6th ed. (London, 1972); contrary, J. B. Cronlin and R. P. Grime, Labour Law, (London, 1970) ch. 10; Selwyn, supra, n. 24; also B. A. Hepple, Intention to create Legal Relations, (1970) 28 C.L.J. 122; P. O'Higgins, Legally enforceable Agreements, (1971) 12 I.R.R.R. 3: R. Lewis, The Legal Enforceability of Collective Agreements, (1970) 8 B.J.I.R. 313.

26 This is the Code effect of the collective agreement; see Kahn.Freund, Labour and the Law 139 et seq.; as to other statutes affecting terms in employment contracts see Employment Protection Act 1975; Contracts of Employment Act 1972; Sex Discrimination Act 1975, Pt. II; Redundancy Payments Act 1965; Race Relations Act 1968 .

27 Id. at 141; see also same author "Legal Framework" in The System of Industrial Relations in Great Britain 58-61: "Report on the Legal Status of Collective Bargaining and Collective Agreements in Great Britain", in Labour Relations and the Law 26-28; as to Scotland see R. L. C. Hunter, Collective Agreements, Fair Wages Clauses and the Employment Relationship in Scots Law, (1975) 20 Juridicial Review 47.

28 Donovan Report, paras. 500 et seq.; the T.U.C. was of the view that "the procedure agreement is not part of the contract of employment"; see Wedderburn and Davies, Employment Grievances and Dispute Procedures in Britain 51.

w In Morgan v. Fry [1968] 2 Q.B. 710 (C.A.), the majority held that the strike did not terminate or breach, merely suspended, the contract; see Kahn-Freund, supra, n. 2, ch. 7, esp. 246-7. 
other industrial action shall not form part of the employment contract unless five conditions are satisfied:

(1) the collective agreement is in writing; and

(2) it contains a provision expressly stating that those terms shall or may be incorporated in the employment contract; and

(3) it is reasonably accessible at his place of work to the worker to whom it applies and is available for him to consult during working hours; and

(4) it is one where each trade union which is a party to the agreement is an independent trade union; and

(5) the employment contract expressly or impliedly incorporates those terms..$^{30}$

The effect of this provision is that while the peace obligation may be directly enforceable in its collective setting as between the social partners, unless all the above requisites are present no contractual enforcement proceedings can be commenced against the individual workers. ${ }^{31}$ Furthermore, the conditions imposed may not be negatived by any arrangement to the contrary either in the collective agreement or in the employment contract. ${ }^{32}$

\section{The United States}

The status of collective agreements was subject to some controversy until the passing of the Taft-Hartley Act in 1947, or more correctly until the authoritative interpretation of its relevant provision by the Supreme Court. Section 301(a) of the Act provides: ${ }^{33}$

Suits for violation of contracts between an employer and a labour organization representing employees in an industry affecting commerce as defined in this Act, or between any such labour organizations, may be brought in any district court of the United States having jurisdiction of the parties without respect to the amount in controversy, or without regard to the citizenship of the parties.

It is indicative of the trade unions' general mistrust of judicial proceedings and preference for settling differences with employers by extralegal methods ${ }^{34}$ that a case commenced on the statute first reached the Supreme Court as late as in 1955. In Association of Westinghouse Salaried Employees v. Westinghouse Electric Corporation ${ }^{35}$ it was held by the majority of the Court that the Act did not alter the substantive character of collective agreements, but merely gave unions the right of action, if they could prove the existence of a contract. A subsequent decision, Textile Workers Union v. Lincoln Mills, ${ }^{36}$ expressed an opposite view holding that the section's purpose was not only jurisdictional but also to provide the necessary legal remedies. The Court posed the question as to what substantive law should be applied and stated: ${ }^{37}$

:0 Trade Union and Labour Relations Act 1974, s. 18(4).

3 See Hepple and O'Higgins, Encyclopedia of Labour Relations Law, 2-1270.

32 Trade Union and Labour Relations Act, s. 18(5); 8. 16 of the Act prohibits the courts to grant specific performance, specific implement, injunction or interdict compelling an employee to do any work, or attend at any place for doing of any work.

33 Taft-Hartley Act or Labour Management Relations Act 1947 amending the Wagner Act or National Labour Relations Act 1935, 8. 301(a).

34 See H. H. Wellington, Labour and the Legal Process, (Yale Univ. Press, 1968), 96 et seq.i N. S. Falcone, Labour Law, (New York, 1962) passim.

35348 U.S. 437 (1955).

36 353 U.S. 448 (1957).

37 Id., per Douglas J. at 456-7. 
[T]he substantive law to apply in suits under 8. 301(a) is federal law which the courts must fashion from the policy of our national labour laws . . . Federal interpretation of the federal law will govern, not state law. But state law, if compatible with the purpose of s. 301 , may be resorted to in order to find the rule that will best effectuate the federal policy. Any state law applied, however, will be absorbed as federal law and will not be an independent source of private rights.

As a result of this decision, a federal "common law" on labour relations developed, ${ }^{38}$ and subsequent cases made clear the contractual enforceability of collective agreements. It was held in a series of decisions ${ }^{39}$ that the grievance arbitration clause in an agreement can be enforced (a) by ordering arbitration and (b) by compelling the observance of the awards, but the courts should not interfere with the merits of an arbitration award.40

The code agreement of a collective agreement is closely connected with its enforceability as a contract. Most agreements start with a purpose and intent clause setting out both their collective and their individual aspects as, to take an example,

(a) to promote and improve industrial and economic relationships between the employees and the company, and

(b) to set forth the basic agreement covering rates of pay, hours of work, and conditions of employment to be observed. ${ }^{41}$

It follows from the primary enforceability that the rates of pay and other conditions must be incorporated in the individual employment contract by law and not merely by extralegal arrangement. When a dispute arises regarding the applicable rate of wages, job classification or any other issue affecting a worker the grievance procedure should be followed. "Grievance" has been defined as a complaint which involves the interpretation or application of or compliance with the provisions of the agreement. ${ }^{42}$ If no satisfactory settlement is reached through the stages of the process, the matter will be referred to arbitration. ${ }^{43}$ At this point, as already has been mentioned, s. 301 of the Taft-Hartley Act may be invoked against the reluctant party. Thus, the breach of the individual employment contract in reality will be redressed through the collective agreement by means of the grievance machinery, though in theory nothing prevents an employee from commencing an ordinary common law action.

By the combined application of the arbitration article and the nostrike clause the collective agreement purports to serve as a peace treaty. The obligation to settle all disputes, whether they affect a single worker or a group of employees, by channelling them through the arbitrator amounts to an abandonment of the right to strike. The question may be asked whether such relinquishment is voluntary, arising from the

3s Wellington, supra, n. 34 at 100.

39 United Steelworkers v. Enterprise Wheel \& Car Corp., 363 U.S. 593 (1960); United Steelworkers v. Warrior \& Gulf Nav. Co. 363 U.S. 574 (1960); United Steelworkers v. American Manufacturing Co. 363 U.S. 564 (1960); see Folke Schmidt, "Industrial Action: the Role of Trade Unions and Employers' Associations", in B. Aaron and K. W. Wedderburn (eds.), Industrial Conflict: $A$ Comparative Legal Survey, (Longman, London, 1972) and 20; G. A. Brown, "The Legal Status of Collective Bargaining and Collective Agreements in the United States of America," in Labour Relations and the Law, ed. Kahn-Freund 48 and 57.

4v United Steelworkers v. Enterprise Wheel \& Car Corp.., supra, n. 39 at 596-597.

"As a typical collective agreement see Agreement Between American Can Company and United Steelworkers of America, Feb. 15, 1974 to Feb. 28, 1977, Art. 1.1; the rates cannot be departed from either downwards or upwards; offer of higher wages was held unfair labour practice by the Supreme Court in $J$. $I$ Case Co. $y$. N.L.R.B., 321 U.S. 332 (1944).

42 Id., Agreement, Article 14.1.

13 Id., Arts. 14.3 and 14.4; see R. D. Horton, Arbitration, Arbitrators and the Public Interest, (1975) 28 Ind. and Labour Rel. Rev. 497. 
contractual force of the collective agreement, or whether it is superimposed by the federal common law as developed after the Lincoln Mills ${ }^{44}$ decision.

A typical no-strike clause provides:

In addition to the responsibilities that may be provided elsewhere in this agreement, the following shall be observed:45

There shall be no union activity on company time which will interfere with or impede production. There shall be no strikes, work stoppages or interruption or impeding of work. No officer or representative of the union shall authorize, instigate, aid or condone any such activities. No employee shall participate in any such activities. There shall be no lockouts by the company.

It appears logical that if the collective agreement contains an express promise similar to the above Article, then there is a contractual duty not to resort to direct industrial action in any manner. The Supreme Court however, in Local 174, Teamsters v. Lucas Four, ${ }^{46}$ went much further. The majority held that a strike was in breach of contract notwithstanding the lack of specific promise not to disrupt work for any reason, as the mere duty to arbitrate implied a no-strike promise. ${ }^{47} \mathrm{Black} \mathrm{J}$. in his dissenting opinion considered the majority judgment as substituting a "court-made contract" for that of the voluntary one of the parties, and described the conclusion of his brethren that a union, without knowing it, impliedly surrendered the right to strike by virtue of 'traditional contract law' as "just fiction". 48 In the view of a learned commentator His Honour was correct, because in collective bargaining agreements the omission of the no-strike clause must be taken as a positive intention not to have it, a "conscious and deliberate choice". 49

Judicial extension thus may broaden the "contractual" peace obligation beyond the parties' intention. While the purpose of ensuring settlement of disputes without strike is praiseworthy, this sacrifice of freedom of contract has given rise to adverse comments. ${ }^{50}$

A strike is a collective action, but the right to strike does not merely concerm the union. It concerns primarily the individual worker. The arbitration clause may be regarded as a procedural one placing an obligation on the union. The right to strike, however, is a substantive matter affecting every single employee, and an express no-strike promise will be incorporated in their contract of employment. It may be presumed that the union negotiators correctly represent the members' will, and they voluntarily contract to abandon this right. If the no-strike clause can be inserted by implication, not only the union itself but the workers lose their contractual freedom, and the assertion that, at least in this respect, contract has been replaced by status will not seem entirely unfounded. 51

\footnotetext{
4 Supra, n. 36.

is American Can Co. and United Steelworkers Agreement, supra, n. 41, Art. 2.2.

16369 U.S. 95 (1962).

17 Id. at 105.

4. Id. at 108-109.

4. Wellington, supra, n. 34 at 115, referring to L. L. Fuller, Basic Contract Law, (St. Paul, Minn., 1947) 764; see also Wellington, Labour and the Federal System, (1959) 26 U.Chi. L. Rev. 542 at 556-8.

so Wellington, id. at 116 et seq.; see also N.L.R.B. v. Insurance Agents' Union, 361 U.S. 477 at 490 (1960).

si In Sinclair Refining Co. v. Atkinson, 370 U.S. 195 (1962); the Supreme Court, however, ruled that federal courts must not issue injunctions to prevent a strike; see Wellington and L. S. Albert, Statutory Interpretation and the Political Process: A Comment on Sinclair v. Atkinson, (1963) 72 Yale L.J. 1547; C. W. Summers, The Individual Employee's Rights Under the Collective Agreement. Nat. Ac. of Arbitrators, Proceedings (1974).
} 


\section{Canada}

The Canadian labour relations system shows more similarity to that of the United States than to that of the United Kingdom, though English decisions have always been regarded as authoritative on points not expressly covered by statute law.52 The prevailing view in Britain that the parties to a collective agreement did not intend it to be enforced through the courts was generally followed until legislation and the influence of judicial decisions in the United States changed the position.

A Privy Council decision, Young v. C.N.R.53 in 1931 approved the pronouncement of the Manitoba Court of Appeal that the "so-called wage agreements entered into between workmen's unions and employers [were] never intended to be legally enforceable agreements", and the terms could not be enforced "through the courts".54 The Judicial Committee was of the opinion that the agreement operated between "a body of employers and a labour organization by which the employers [undertook] that certain rules beneficial to the workmen [should] be observed", but "the fact the railway company had applied the provisions of [the agreement] to all its employees did not necessarily indicate that it was contractually bound . . . because it may have done so simply as a matter of policy". Further, the learned lords stated that the agreement did not appear "to be a document adapted for conversion into or incorporation with a service agreement." 55 Consequently, the union had no legal means ensuring that the rules which the railway company undertook to observe when employing workmen would in fact have become terms of the service contract, and the employee similarly had no right to rely on them as terms of his contract by tacit incorporation. Presumably the only way to ensure their transference into the service contract was by reciting all of them in detail. Express reference to the relevant rules, perhaps, would have been sufficient incorporation, but the employer in any case could not be compelled to accept such demands. The remedy open was nothing less than "the calling of a strike". ${ }^{56}$

By the 1960s, however, as a result of statutes passed 57 and the acceptance of the principles formulated by the United States Supreme Court in the Steelworkers' Trilogy, ${ }^{58}$ the British Columbia Supreme Court in Nelson Laundries v. Manning was able to declare unequivocally that "collective agreements have become and are accepted as agreements which do create obligations enforceable at law".59 The machinery of grievance arbitration built into the collective agreements was a prerequisite to judicial enforcement, as an award when filed be-

52 See for e.g. Russell v. Amalgamated Society of Carpenters \& Joiners, [1912] A.C. 421 quoted in Polakoff v. Winter Garments Co., [1928] 2 D.L.R. 277 (Ont. H.C.); Taft Vale Railway Co. v. Amalg. Society of Railway Servants, [1901] A.C. 426 quoted in International Brotherhood of Teamsters v. Therien, (1960) 22 D.L.R. (2d) 1 (S.C.C.).

ss [1931] A.C. 83; see also Aris v. Toronto, Hamilton, \& Buffalo R. Co., [1931] 1 D.L.R. 634; Wright et al. v. Calgary Herald, [1938] I D.L.R. 111; Bryson v. Glenlawn School District, [1944] 3 D.L.R. 636.

34 [1930] 3 D.L.R. 352 at 357.8.

ss [1931] A.C. 83 at $88-9$.

s6 Id. at 89.

57 Industrial Relations and Disputes Investigation Act 1948 (following the U.S. Wagner Act 1935 and Taft. Hartley Act 1947); similar statutes were passed by British Columbia, Alberta and Nova Scotia in 1947, by Manitoba and Ontario in 1948, by New Brunswick in 1949 and by Newfoundland in 1950; the Saskatchewan Trade Union Act 1947 was somewhat different; Alberta Labour Act 1955; British Columbia Mediation Commission Act 1968; Manitoba Labour Relations Act 1954; Quebec Labour Code 1954; Ontario Labour Relations Act 1960, Rights of Labour Act, Ontario 1960; for the most recent statutes see infra, n. 68 .

sk Supra, n. 39.

iy (1965) 51 D.L.R. (2d) 537 at 542; (B.C.S.C.). 
came enforceable in the same way as a judgment or order of the court.60 In International Chemical Workers' Union v. Consumers' Gas Co. the Ontario High Court on the analogy of the execution of judgments held that the remedies of attachment, committal and sequestration could be granted to compel compliance with the award, ${ }^{61}$ but the Supreme Court of Canada in Hamilton Street Railway Co. v. Northcott allowed damages to the individual employees after successful arbitration proceedings. ${ }^{62}$ A breach of award also could give ground for criminal prosecution. ${ }^{63}$

Judicial approach in Canada markedly differed in one important aspect from that in the United States: Canadian courts did not hesitate to interfere with the merit of awards by the application of the "excess of jurisdiction" and "error in law" principles. In $R$. v. Barber, Ex parte Warehousemen's and Miscallaneous Drivers' Union ${ }^{64}$ the Ontario Court of Appeal dismissed the appeal against the order of the lower court ${ }^{65}$ which set aside the majority award of a board of arbitration constituted under a collective agreement, and remitted it for reconsideration. The proceedings were commenced by way of certiorari. The Court of Appeal through Jessup J.A. after examining the award stated:66

There are many cases in this Court where awards of labour arbitrators have been set aside in proceedings by way of certiorari by reason of excess of jurisdiction assumed under a construction of provisions of a collective agreement which was erroneous in law. As a result of the reviewable errors of law that I have mentioned the majority of the board was led to act without or in excess of jurisdiction by in effect amending the agreement. I have no doubt that this resulted in a substantial wrong to the grievor and a miscarriage of justice within the meaning of 8.86 of the statute.

Federal legislation has now firmly established the legal binding force of collective agreements, but at the same time has restricted the role of the courts to the judicial enforcement of arbitration awards, as distinct from interfering with their merits on any grounds. Thus, after a period of developing in a different direction, the Canadian law in this respect has assimilated to that of her giant neighbour over the border. ${ }^{67}$

The Canada Labour Code, as amended, ${ }^{68}$ provides that a collective agreement entered into between a bargaining agent and an employer in

so Ontario Labour Relations Act 1970, 8. 34(9).

s1 (1964) 41 D.L.R. (2d) 119 (Ont. H.C.).

82 (1966) 58 D.L.R. (2d) 708 (S.C.C.).

63 Correctly: breach of $8.34(8)$ of the Ontario Labour Relations Act resulting from non-observance of an award gives ground for prosecution under 8. 69.

of (1968) 68 D.L.R. (2d) 682 (Ont. C.A.).

os [1967] 2 O.R. 541 .

ab (1968) 68 D.L.R. (2d) 682 at 691; as to criticism on review by the court see P. C. Weiler, The Slippery Slop of Judicial Intervention (1971) 9 Ösgoode Hall L.J. 1; The Arbitrator, the Collective Agreement and the Law (1972) 10 Osgoode Hall L.J. 141; G. W. Adams, Grievance Arbitration and Judicial Review in North America (1972) 10 Osgoode Hall L.J. 141; G. W. Adams, Grievance Arbitration and Judicial Re
(1971) 9 Osg. Hall LJ. 443; see also Re United Steelworkers [1975] 53 D.L.R. 8 (Ont.).

6: Ramifications of this issue, further difficulties arising from the unions' unincorporated status and other obstacles of enforceability cannot be discussed within the narrow confines of this article; see International Brotherhood of Teamsters v. Therien (1960) 22 D.L.R. (2d) I (S.C.C.): Nipissing Hotel Led. v. Hotel and Restaurant Employees and Bartenders International Union (1963) 38 D.L.R. (2d) 675 (Ont. H.C.); see also D. J. Sherbaniuk, Actions By and Against Trade Unions in Contract and Tort (1958) 12 U.T.L.J. 151; J. C. Cameron \& F. J. L. Young. The Status of Trade Unions in Canada, (Kingston 1960) 113 et seq.; A. W. R. Carrothers, Collective Bargaining Law in Canada. (Toronto, 1965); H. L. Molot, The Collective Labour Carrothers, Collective Bargaining Law in Canada, (Toronto, 196); H. Christie, The Liability of Strikers in Agreement and its Agency of Enforcement (1967) 5 Alta. L.R. 274; I. M. Christie, The Liability of Strikers in Agreement (Kingston, Ont, 1966); L. Adell, The Legal Status of Collective Agreements in England, the United States and Canada (Kingston, Ont., 1970).

6x Canada Labour Code 1970 as amended by Amendment Statute dated July 7, 1972, 21 El. c. 18; see also the Trade Unions Act, R.S.C. 267; The Labour Code of British Columbia (1974) 9 U.B.C.L.R. 280; Manitoba Labour Relations Act 1972; Ontario Labour Relations Act 1970; Saskatchewan Trade Union Act 1972; Quebec Labour Code 1964 as amended in 1965, 1969, 1970 and 1971. 
respect of a bargaining unit is binding upon

(a) the bargaining agent being the duly certified union;

(b) every employee in the bargaining unit, and

(c) the employer. ${ }^{69}$

This section makes it clear that the employees are primary parties to the collective agreement and not only bound by the service contract which incorporates its relevant terms.

The Code makes it mandatory to include in every collective agreement a provision for final settlement of all differences by arbitration or otherwise without stoppage of work. Where there is no such provision the Canada Labour Relations Board will furnish one, and it "shall be deemed to be a term of the collective agreement".70 The decision of an arbitrator or an arbitration board, contrary to previous judicial practice, will be final and "shall not be questioned or reviewed by any court" by injunction, certiorari or otherwise. ${ }^{71}$ The arbitration order or decision may be filed after fourteen days of its date in the Federal Court of Canada, and upon registration in the Court it will have "the same force and effect, and all proceedings may be taken thereon, as if the order or decision were a judgment obtained in the Court". ${ }^{72}$

Courts of law, thus, have been given express power to enforce arbitration decisions, but not to review them, or in any way interfere with their merits. The interpretation of a collective agreement is entirely the task of the arbitrator or arbitration board acting within the four corners of the settlement provision as included or deemed to be included in the collective agreement. ${ }^{73}$ The Canada Labour Relations Board is the statutory body to which the arbitrator or any party to the proceedings may refer certain well defined questions for determination. ${ }^{74}$ The Board's decisions and orders are enforceable as judgments of the Federal Court and, except in accordance with 8 . 28 of the Federal Court Act, they cannot be reviewed or otherwise questioned. ${ }^{75}$

\section{E. Australia}

The enforceability of collective agreements may be described as a non-issue in Australia. The conciliation and arbitration system that has been in existence for many years places the emphasis on awards made by the Conciliation and Arbitral Commission. ${ }^{76}$ Collective agreements, or more correctly called, industrial agreements, play a secondary role.

"Arbitration" and "award"77 in the context of Australian legislation are given a meaning basically different from the sense in which these words are used in the United States and Canada. In North America

sy Canada Labour Code, 8. 154.

io Id. 8. 155 .

iI Id. 8. 156.

i. Id. 8. 159.

iId. at 8.157.

74 Id. 88. $111 \cdot 123,157$.

7s Id. 88. 122 and 123.

it The Conciliation and Arbitration Act (Commonwealth) 1904-1976 (hereinafter in this Part quoted as "the Act"); s8. 6-17 refer to the constitution of the Commission, 88. 18-889 to its powers and functions.

"7 "Arbitration" as such is not defined in the Act, but $88.16-88 \mathrm{~g}$ make its Australian meaning adequately clear. "Award" means an award made under the Act, including an order, the sections quoted above contain detailed provisions as to the system see $O$. D. R. Foenander, Industrial Conciliation and Arbitration in Australio (Sydney 1959); J. J. Macken, Australian Industrial Law, (Sydney 1974); J. E. Isaac and G. W. Ford (eds.), Australian Labour Relations (Melbourne, 1968); J. E. Isaac, Compulsory Arbitration in Australia. No. 14, (Canadian Task Force on Labour Relations, 1970). 
arbitration is a process resorted to as the last stage of the grievance machinery, in accordance with the procedure set out in the collective agreement itself, for the purpose of settling differences arising from the application and interpretation of the same agreement. ${ }^{78}$ Contrariwise, in Australia, arbitration and also conciliation that must precede it function for the very purpose of creating a collective instrument between the parties to the dispute. The instrument may take the form of an industrial agreement when the parties have succeeded in reaching settlement either voluntarily, or through conciliation; if they are not able to agree the Commission will determine the matters in dispute, and its decision, the award, will be superimposed on the parties.79 Thus, while in North America arbitration arises from the collective agreement, in the collective instrument itself, the award, is the product of arbitration.

The decision of the Commission making the award will be final and conclusive. It cannot be challenged, appealed against, reviewed, quashed or called in question in any court on any account by way of prohibition, mandamus, injuction or otherwise. ${ }^{80}$ The award binds all parties to the dispute (a) who appeared or were represented, (b) who were summoned or notified whether they appeared or not and (c) who having been notifed as alleged parties did not satisfy the Commission that they should not be so bound. In the case of employees it binds a successor, assignee or transmittee of a party, including a corporation. Further, the binding force extends to all organizations and persons on whom the award is binding as a common rule, and to all members of organizations bound.81 The identification of the parties is most important, 82 because a federal award binds only the parties to the dispute as specified by the Commission, unless it declares that "any term of the award shall, in a Territory, be a common rule of any industry in connection with which the dispute arose."83 A state award, in contradistinction, unless exempted, "shall be binding on any or all employers and employees engaged in the industry or calling ... within the locality and for the period . . . specified."84

Enforcement of awards is by way of imposition of penalties for breach or non-observance. Proceedings may be started either before the Australian Industrial Court, or, except in bans clause cases, before any District, County or Local Court or Court of summary jurisdiction. ${ }^{85}$

Only certain specified persons or organizations may sue:

(a) the Registrar of the Industrial Court; or

in Supra, n. 76, Sections II.D and E.

74 The Act 8. 30 et sea.; H. J. Glasbeek and E. M. Eggleston, Cases and Materials on Industrial Law in Australia, (Sydney 1973) 81-97; E. Sykes, "Labour Arbitration in Australia", K. J. Hancock, "Compulsory Arbitration versus Collective Bargaining", and K. M. Laffer, "Compulsory Arbitration and Collective Bargaining" in Isaac and Ford (eds.), supra, n. 77 at 286, 442 and 455 resp.

so The Act, 8. 60; see Clothing and Allied Trades Union of Australia v. Cocks (1968) A.I.L.R. Rep. 79, R. v. Commonwealth Industrial Court, exp. Cocks (1968) 121 C.L.R. 313; Commonwealth Steamship Owners Assn. v. Waterside Workers Fed. of Aust. (No. 2) (1963) 5 F.L.R. 103; Coal Miners' Union, Collie W.A. v. Amalg. Collieries of W. A. Led. (1960) 104 C.L.R. 437.

81 The Act, 8. 61; R. v. Portus and Quantes Empire Airways Ltd., ex.p. MicNeil (1961) 105 C.L.R. 537; W. Angliss and Co. Pty. Led. v. A'asian Meat Industry Employees' Union (1966) 7 F.L.R. 402; Woodhouse v. Peter Brotherhood Led. [1972] 3 All E.R. 91.

o2 The Ach 8. 24(1) provides that "the Commission shall determine . . who are the parties"; Re Pastoral Industry Award (1956) 86 C.A.R. 645; Re Graphic Arts Award, Re Long Service Leave (1959) 92 C.A.R. 552.

s3 The Act, s. 49(1); Re Long Service Leave (N.T. and A.C.T. Awards (1964) A.I.L.R. Rep. 12.

s Industrial Arbitrators Act 1940 (N.S.W.) s. 87; Re Private Hospitals (State) Award (1964) A.R. 616; Industrial Conciliation and Arbitration Acts 1961-64 (QId.); Industrial Arbitration Act 1912-1968 (W.A.); Labour and Industry Act 1958 (Vic.); Wages Board Act 1920 (Tas.); Industrial Code 1967.70 (S.A.).

ss The Act, 8. 119(1); Amalg. Eng. Union v. Keefer Bros. Pty. Ltd. (1942) 47 C.A.R. 561; Thomas Borthwick and Sons (D'asia) Led. v. Crowton (1959) 3 F.L.R. 459. 
(b) an Inspector, specially appointed; or

(c) any organization which is affected, or whose members, or any of them are affected, by the breach; or

(d) any member of any organization who is affected by the breach, or

(e) any party to the award or order;

(f) any officer of any organization which is affected, or any of whose members are affected, by the breach, who is authorized under the rules of the organization to sue on its behalf. ${ }^{86}$

Where there is a breach of a bans clause a special procedure applies, and only the Commission can take the requisite remedial action. A bans clause is a term of an award, however expressed, which prohibits engaging in conduct that would hinder, prevent or discourage (a) the observance of the award, (b) the performance of work in accordance with it, and (c) the acceptance of, or offering for, work in accordance with the award. ${ }^{87}$

It is of interest that an individual member himself may take action for imposition of the penalty. Further, the Act expressly provides that any employee entitled to the benefit of the award, may, at any time within six years from the payment becoming due to him, sue for the amount either in the Industrial Court or in any court of competent jurisdiction ${ }^{88}$ In True v. Amalgamated Collieries of W.A. $L t d{ }^{89}$ the Privy Council held that the limitation period, originally prescribed as twelve months, did not apply, as the employee could recover under his contract of service.

As far as industrial agreements are concerned two types can be distinguished. The first type is made during the negotiation or concilation process, but in any case before the dispute has been referred to the Commission for arbitration. The parties may either prepare a memorandum of the terms agreed, or submit their agreement for inclusion in an award. In both cases a member of the Commission will be requested to certify the memorandum, or make an award giving effect to the agreement, as the case may be. If the member is satisfied and complies with the request, a certified memorandum or an award made by consent, will have "the same effect as, and shall be deemed to be, an award of the Commission for all purposes of the Act."90 Such an instrument is binding on

(a) each party making the request,

(b) all members of an organization that is a party, and

(c) an employer who is a successor to, an assignee or transmittee of, the business of a party, including a corporation that has acquired or taken over the business.91

The other type of industrial agreement does not arise from a dispute. It may be made by an organization with any other organization or with

so The Act, 8. 119(2); Collins v. Dix (1971) A.I.L.R. Rep. 408; Inspectors are appointed under 8. 125 for the purpose of enforcing the observance of the Act, regulations and awards.

87 The Act, 8. 33; as to enforcement of bans clauses see the detailed discussion in C. P. Mills and G. H. Sorrell, Federal Industrial Law (Sydney 1975) paras. 657-661.

so The Act, 8. 123 Blackley v. Devondale Cream Vic.J Pty. Ltd. [1968] A.L.R. 307; Tucker v. Canatelli (Ind. App. Ct.) (1968) A.I.L.R. Rep. 276.

89 [1940] A.C. 637 (P.C.); the limitation period under the Industrial Arbitration Act 1912-1935 (W.A.) was twelve months only; see also Mallinson v. Scottish Australian Investment Co. Ltd. (1920) 28 C.L.R. 66 .

90 The Act, o. 28(1) (3); Printing and Kindred Industries Union and Hogbin Poole (Printers) Pty. Ltd. (1968) 122 C.A.R. 509, Re Atkinson.Holland and Aust. Workers' Union (1969) A.I.L.R. Rep. 504.

91 The Act, 8. 28(4). 
any person for the prevention and settlement of existing or future industrial disputes by conciliation or arbitration. This is always a voluntary agreement and binds all the parties to it including all members of any organization which is a party, but cannot be extended to effect further organizations or persons. The method of enforcement is the same as that applicable to breach of awards. ${ }^{92}$

\section{THE CHARACTER AND BINDING FORCE OF COLLECTIVE INSTRUMENTS IN NEW ZEALAND}

\section{A. Disputes of Interest and Disputes of Rights}

The New Zealand system of settling industrial disputes at first sight appears very much the same as that of Australia but upon deeper examination significant differences can be observed. ${ }^{93}$ Notwithstanding that conciliation and arbitration functions for the purpose of creating collective instruments, there is also machinery for American-type grievance 94 arbitration, though the word "arbitration" is not used in this context. The distinction between the two types of dispute has been recognized by legislation, and they have been termed "dispute of interest" and "dispute of rights". The former is defined as "a dispute created with intent to procure a collective agreement or award settling terms and conditions of employment of workers in any industry."95 The wording clearly indicates economic targets mixed with social and political objectives as the essence of the dispute. The parties engage in the process of bargaining in order to secure the best possible terms to be included in the resulting instrument. Expressed otherwise, they have no rights yet under a collective agreement or award: they have merely interests that they are endeavouring to transform into rights by concluding a settlement and reducing it to a written document.

On the contrary, a dispute of rights presupposes the existence of a written instrument, as it concerns the interpretation, application or operation of a collective agreement or award, and of an enactment or an employment contract if the dispute relates to a collective agreement or award. A personal grievance is also included in the definition of dispute of rights. Although the extension of the meaning to "any dispute that is not a dispute of interest, including any dispute that arises during the currency of a collective agreement or award" makes the definition somewhat open-ended, there can be no doubt that a dispute of a purely legal character is envisaged.96 A situation may occur where the dispute does not clearly fit in either category. The Act provides that in such a case the nature of the dispute shall be determined by the Industrial Court.97

92 The Act, s8. 172, 173, 176 and 177; Re Electricity Trust of S.A. Agreement (1962) 100 C.A.R. 876; Re Federal Capital Press of Australia Pty. Ltd. Agreement (1962) 100 C.A.R. 878; Public Service Assn. v. Royal Aust. Nursing Federation (1972) A.I.L.R. Rep. 667.

93 See N. S. Woods, Industrial Conciliation and Arbitration in New Zealand (Wellington, 1963); S. J. Callahan (ed). Wage Fixing in New Zealand (Wellington 1968); A. Szakats, Trade Unions and the Law (Wellington, 1968); D. L. Mathieson, Industrial Law in New Zealand, (Wellington, 1970), J. M. Howells, N. S. Woods and F. K. L. Young (eds.), Labour and Industrial Relations in New Zealand (Pitman, 1974).

24 "Grievance" in the American sense includes all disputes to be settled under the collective agreement; in New Zealand there are separate procedures for group disputes of rights, and individual disputes of rights called grievances: Industrial Relations Act, 1973 (hereinafter quoted as I.R. Act), s. 115-117.

95 I.R. Act, s. 2.

yo Id., see also Woods, The Industrial Relations Act 1973, (Ind. Rel. Centre, V.U.W., 1974); B. G. Hansen, Industrial Relations Reform in New Zealand: Comments on the Industrial Relations Act 1973 (1974) 7 V.U.W.L.R. 300; J. Seidman, New Zealand's Industrial Relations Act 1973 (1974) 110 International Labour Review, 515.

97 I.R. Act, 8. 47(3); formerly, under the repealed Industrial Conciliation and Arbitration Act 1954 (hereinafter 
A collective agreement may result either from voluntary settlement ${ }^{98}$ or from conciliation. If free bargaining fails, either party ${ }^{99}$ may apply to a conciliation council. ${ }^{100}$ Where the applicant is an industrial union of workers all organizations of employers in the district in any industry to which the dispute relates must be named as respondents; where there is no such organization, a number of representative employers should be named. In either case all the employers in the relevant industry or industries "shall also be deemed to be respondents". ${ }^{101}$ As a consequence of this blanket citation all employers will be original parties not only to the proceedings but also to the settlement, if achieved. It is irrelevant whether or not they have in fact been represented. As a logical consequence they are in the same position when the dispute goes for arbitration to the Industrial Commission. ${ }^{102}$

\section{B. Agreement or Decree?}

Accordingly three types of collective instruments are distinguished by the Act. These are:

(1) Voluntary collective agreements, ${ }^{103}$

(2) Conciliated collective agreements, ${ }^{104}$ and

(3) Awards. ${ }^{105}$

The award has been described as "in form a judicial decree, but in substance on act of legislative authority," as the real function of the Industrial Commission is to act as a "delegated and subordinate legislative authority."106 The regulatory and normative effect is enhanced by the blanket clause extending the binding force of the award to contingent future parties who at any time during its continuance will be connected with, or engaged in, the industry. ${ }^{107}$

Both types of collective agreements must be registered ${ }^{108}$ with the Commission in order to be recognized as such, but despite the identical

quoted as "I.C. \& A. Act) the Arbitration Court had jurisdiction in both types of dispute now the Industrial Commission (hereinafter unless, the context otherwise indicates called "the Commission") is the arbitrating. award making body, and the Industrial Court (hereinafter unless, otherwise indicated is referred to as "the Court") exercises judicial power in rights disputes: I.R. Act 88. 17-31 and 88. 32-62 resp.

95 I.R. Act, 8. 65; a voluntary agreement made between one or more employers in any undertaking or group of undertakings and a number of unions or associations representing workers engaged upon different trades or calling within the undertakings or group of undertakings is called a composite agreement: 8. 66 , see $N . Z$ Timber Workers I.U.W. v. Hutt Timber Co. Ltd. (1972) 72 B.A. 3308, Re Fletcher Construction Co. Ltd.'s Application (1974) 74 B.A. 981.

99 The parties are registered industrial unions of workers and registered industrial unions of employers or individual employers; registration is not compulsory but it is said to have advantages: I.R. Act 88. 163-174 and words quoted, supra, n. 93 and 96.

100 I.R. Act, 38, 67-83; it is to be noted that the dispute will be conciliated only if one of the parties make an application to that effect, and the other agrees to nominate assessors to the conciliation council; see Northern. etc., Foremen Stevedores, Timekeepers and Permanent Hands' Industrial Agreement (1972) 72 B.A. 1778.

101 I.R. Act, 8. 68(5).

102 Id. s8. 84-90, the decisions of the Commission and of the Court cannot be challenged, appealed against. reviewed, quashed or called in question in any Court except on the ground of lack of jurisdiction: 8s. 26(4) and 47(6) reenacting I.C. \& A. Act, 8. 47 relating to the former Court of Arbitration; N.Z. Engineering. Coachbuilding, etc., I.U.W. v. Court of Arbitration and Others [1976] 2 N.Z.L.R. 283 (C.A.); N.Z. Waterside Workers Fed. I.A.W. v. Frazer [1924] N.Z.L.R. 689, (S.C.); Wellington District Hotel, etc., Union of Workers v. A.G. [1951] N.Z.L.R. 1072 (C.A.); N.Z. Sheepowners I.U. of Employers v. Tyndall [1960] N.Z.L.R. 606 (S.C. \& C.A.).

103 Id. 8. 65.

104 Id. 8s. 82 and 83; see Inspector of Awards v. Waikato Metal Supplies Ltd. (1974) 74 B.A. 227; Re Taranaki Wellington and Canterbury Coal Store, etc., Employees' Award (1974) 74 B.A. 767; Inspector of Awards v. Cooper (1968) 68 B.A. 1931; Inspector of Awards v. Domett Truck and Trailer Co. Ltd. (1970) 70 B.A. 5081.

105 Id. s8. 86 and 89 .

106 New Zealand Waterside Workers' Federation I.A.W. v. Frazer [1924] N.Z.L.R. 689 (S.C.) at 709, relating to the former Arbitration Court (per Salmond J.).

107 I.R. Act, s8. 83(1) and 89(2).

lus Id. $\mathrm{s8} .65(3)$ and $82(2)$ resp. 
name distinguished merely by the adjectives "voluntary" and "conciliated" only the voluntary collective agreements can be regarded as true agreements resulting from the parties' genuine common will freely arrived at without interference by any outside person or body. Conciliated collective agreements are more akin to awards, partly on account of their tripartite method of "agreeing", and partly because of their identical binding force. Under the former Act the blanket clause was attached only to awards, and to achieve its effect the parties, when they reached a conciliated settlement instead of entering into an industrial agreement, could request the Arbitration Court to incorporate the terms agreed in an award. The Court had power to do so without a further hearing. ${ }^{109}$

The new legislation eliminated this roundabout method.110 The change might have been prompted by the realization based on past experience that in negotiating with the benevolent guidance of a conciliation council the parties practically are under the same pressure as in arbitration proceedings. Though the council has no power to make a decision, it "shall make all such suggestions and do all such things as it thinks right and proper for inducing the parties to come to a fair and amicable settlement". ${ }^{111}$ It has been pointed out that in the last 20 years before the repeal of the I.C. \& A. Act about 80-90 percent of the disputes were settled by conciliation, the main reason being "knowledge of the [Arbitration] Court's likely attitude" which "in fact exert[ed] a strong influence upon the negotiations in council". ${ }^{112}$ There can be no doubt that the criteria of free bargaining to a great extent are absent from conciliation proceedings, and the agreement reached under pressure may with some justification be denoted as an award by persuasion.

\section{Form and Substance}

As far as the form and substance are concerned, agreements and awards follow the same pattern. Clauses in all of them can be divided into three distinct groups:

(1) Individual: those which are to be incorporated in the individual contract of employment.

(2) Collective: those which will not be so incorporated, as they affect only the union itself.

(3) Mixed: those which affect the worker but also the union itself, and therefore are deemed to be incorporated in the individual service contracts.

Wages and conditions of work comprise the first group: in short, matters that strictly relate to the employment relationship. The second group refers to issues between the employer and the union such as: definition of the industry to which the instrument applies, deduction of union dues from wages, the union secretary's right of entry, and similar matters which do not directly concern the employee. Clauses in the third group regulate rights disputes, grievance procedure and preferential

\footnotetext{
iv9 I.C. \& A. Act, s. 108 (repealed); collective agreements under the former Act were called industrial agreements as those in Australia still are.

110 I.R. Act, s. 83(1) gives all conciliated collective agreements the blanket application force; 8.83 is applicable to awards: $8.89(2)$.

III Id. s. 77(2).

112 P. J. Luxford, "The Industrial Conciliation and Arbitration Act in Practice", in Wage Fixing in New Zealand, ed. S. J. Callahan, (London, 1968) 42; see also N. S. Woods, "Industrial Relations in the Private Sector" in Labour and Industrial Relations in New Zealand, J. M. Howells, N. S. Woods and F. H. L. Young (eds.) 88.
} 
employment of union members. ${ }^{113}$ These matters equally affect both the individual worker and the union.

In its form and structure, a conciliated settlement still remains a collective agreement. The Order of the Industrial Commission which precedes the Schedule setting out the detailed terms and conditions differs from the formula used in awards, but follows, with some important alterations, that prefacing voluntary agreements. An award, after the usual heading naming the parties proceeds as follows:

The Industrial Commission having taken into consideration the matter of the above mentioned dispute of interest, and having heard the union by its representatives duly appointed, and having also heard such of the employers as were represented either in person or by their representatives duly appointed, doth hereby order and award:

That the terms, conditions and provisions set out in the Schedule hereto shall be binding on the parties to this award, and that the said terms, conditions and provisions shall be deemed to be and they are hereby incorporated in and declared to form part of this award; and further that the said parties shall respectively do, observe and perform every matter and thing by this award required to be done, observed, and performed, and shall not do anything in contravention of this award but shall in all respects abide by and perform it.

The Order concludes with the date, the seal of the Commission, the signature of the President, and then the Schedule follows.

Conciliated collective agreements are introduced with a differently worded preamble:

The Industrial Commission having before it the terms of a conciliated settlement arrived at in the above-mentioned dispute of interest and notified to the Commission pursuant to the provisions of section 82 of the Industrial Relations Act 1973, hereby registers as a collective agreement the terms, conditions, and provisions set out in the schedule hereto, and orders:

(1) That the said terms, conditions and provisions shall be binding on the parties hereto; and

(2) That the said parties shall respectively do, observe, and perform every matter and thing by this collective agreement required to be done, observed and performed, and shall not do anything in contravention of this collective agreement but shall in all respects abide by and perform it.

The formula introducing voluntary collective agreements differs only in three respects:

(1) instead of "conciliated" the word "voluntary" is substituted before "settlement";

(2) between the words "dispute of interest" and "and notified" the words "submitted or" are inserted; and

(3) the reference is to s. 65 instead of 8.82.

It is significant that the Commission makes an Order not only in an award, which by its very nature must be on account of the parties' failure to agree a superimposition of the tribunal's decision, but also in a registered collective agreement expressly providing that "the terms, conditions, and provisions shall be binding on the parties hereto". The obligations arising from the agreement itself as if it were a contract, and the methods of enforcement available at common law, obviously are insufficient for several reasons. First, enforcement is intended within the framework of, and through the breach of award process prescribed in,

113 I.R. Act, 88. 98-104; as to exemption 88. 105-112 see Szakats, Compulsory Unionism: A Strength or Weakness? (1972) Alta. L.R. 313; see Taranaki Amalg. Soc. of Shop Assistants, etc., I.U.W. v. I. J. Dunbar and Another (1975) 75 B.A. 4515; Actors Equity of N.Z. I.U.W. v. Reynold Television Ltd. and Others (1975) 75 B.A. 5275. 
the Act. Second, the expression "parties hereto" carries a much wider connotation than in a common law contract.

\section{Primary, Secondary and Contingent Parties}

Parties to an award or a conciliated collective agreement can be classified in the following categories:

1. Primary original parties, being either

(a) named in the instrument, or

(b) unnamed but expressly brought in as "deemed respondents" in accordance with s. 68(5), the blanket citation clause.

2. Secondary or positional original parties who by virtue of their position as members of an organization that is an original party are expressly made parties by the statute; these may be subdivided into four groups:

(a) individual members of a union that is an original party: s8. $82(4)$ and $89(1)$.

(b) a member union of an association that is an original party: ss. $82(4)$ and $89(1)$.

(c) individual members of a union that is a member of an association being an original party: s8. 82(4) and $89(1)$.

(d) every worker who is at any time while the collective agreement is in force employed by an employer on whom the agreement is binding in any employment to which the agreement relates: ss. $82(8)$ and $89(2)$.

3. Subsequent future and contingent parties bound by virtue of the blanket clause embodied in 8. 83(1) of the Act being

(a) every union,

(b) every association, or,

(c) every employer

who, not being an original party, is, when the agreement comes into force or at any time while it is in force, connected with or engaged in the industry to which the agreement applies within the area to which the agreement relates: s. $89(2)$ as to awards; and

(d) every worker employed by an employer coming under paragraph (c) at any time while the agreement is in force: ss. $82(8)$ and $89(2)$.

Although members of an industrial union of workers are expressly bound by subs. (4) of s. 82 , the provision in subs. (8) extending the agreement's binding force to "every worker" as distinct from union members is necessary to cover those who have not yet joined the union but would be obliged to do so under the preference clause, unless granted exemption. Furthermore, it is to be noted that s. 82(8) refers to two groups of workers: (a) those who are already employed by an employer being a primary or secondary party when the agreement comes into force, and (b) those who will be employed by an employer being a subsequent party at a later stage.

The circle of parties bound by a voluntary collective agreement is much smaller, notwithstanding that the first two categories are essentially the same: 
1. Primary original parties named in the agreement and signing the submission of voluntary settlement: s. 65(3).

2. Secondary or positional original parties who are the same as in case of conciliated agreements with the exception of "every worker" specifically included by s. $82(8)$; this subsection has been omitted from s. 65, therefore non-union workers prima facie do not seem to be bound; but if they are in employment, as the relevant terms of the collective agreement form part of the service contract by incorporation, the omission does not significantly affect their position: s. 65(5).

3. Added parties; during the currency of the agreement any further union, association or employer within the area to which it relates may with the consent of the original parties join the agreement by filing a notice of concurrence with the Registrar of the Commission: s. 65(6).

The added parties with the acceptance of their concurrence will in effect become primary parties, and, in case of unions and associations their members ipso facto will be in the position of secondary parties. ${ }^{114}$

Manifestly, beyond the primary and secondary parties, voluntary collective agreements can be extended only by further voluntary acts of concurrence and consent. The bipartite method of settlement and the bilateral contractual character of the agreement, thus, are preserved, notwithstanding that in fact there can be several parties on both sides. In contradistinction, by virtue of the very provisions of the I.R. Act, a conciliated collective agreement is assimilated to an award and assumes the character of delegated legislation with an erga omnes binding force. Subsequent parties will be bound by its terms, regardless, or even against, their volition; although on application by any union, association or employer the Commission may grant total or partial, unconditional or conditional, exemption from the collective agreement, ${ }^{115}$ its prima facie general applicability will not be affected. The public regulatory quality would necessarily restrict the Schedule to clauses of more common and usual nature throughout the industry concerned, whereas a voluntary collective agreement, for the very reason of being bilateral and freely arrived at, can be more specific. It may be used as a vehicle for genuine in-plant negotiations embracing (besides the basic matters) detailed arrangements that are particular and relevant to one workplace only, or in exceptional cases to a few workplaces connected by some common factors, such as the identity of the employer and of work processes involved.

\section{E. Enforcement of Collective Instruments}

Collective agreements and awards are enforceable by action for recovery of penalties for breach brought by any party, or by an Inspector of Awards and Agreements. ${ }^{116}$ Not only the primary, but also the secondary, parties may commit a breach and incur liability. The statute provides that if "any employer, worker, union or association, or any combination of either employers or workers" has acted with

\footnotetext{
114 See Szakats, Introduction to the Law of Employment, (Wellington, 1975) para. 51.

115 I.R. Act, ss. 82(5) (6) (7), 83(2) (3) (4) and 89.

118 I.R. Act, 88. 148 and 151; Inspectors are appointed under the Act; see Inspector of Awards v. Allied Industries Ltd., re North Island Radio and Associated Electronic Employees Coll. Ag. (1975) 75 B.A. 6731 (Ind. Ct.); see also Factories Act 1946 8. 34(6) which gives similar but not exactly the same powers to an Inspector of Factories.
} 
intention to defeat any provisions of an industrial instrument, "the employer, worker, union, association, or combination, and every member thereof respectively, shall be deemed to have committed a breach".117 The maximum penalty is $\$ 400$ for unions, associations or employers and $\$ 40$ for workers in respect of every breach. ${ }^{118}$

The Industrial Court has exclusive jurisdiction in all such actions, ${ }^{119}$ and its judgments may be enforced through a Magistrate's Court.120 If a judgment against a union or association is not satisfied within one month, all persons who were members when the offence was committed will be jointly and severely liable on the judgment in the same manner as if it had been obtained against them personally. Execution process may be taken against any of them, but their liability cannot exceed $\$ 20.121$

Wages and all moneys due to individual workers under an award or collective agreement may be recovered by way of proceedings for breach. The action is to be brought by an Inspector of the Industrial Court, and it may be joined with penalty proceedings against the same employer. Unpaid moneys, including the balance between the actually paid lower rates and the award rates, can be claimed to the use of the worker, even though he accepted a smaller sum without protest under an express or implied agreements in full satisfaction. ${ }^{122}$ The Inspector may elect to sue in an ordinary court for the recovery of wage arrears and all unpaid moneys in the name and on behalf of the worker. ${ }^{123}$ In both cases remedies otherwise available are expressly preserved, ${ }^{124}$ and this primarily must mean a common law action by the worker. The statute also provides that the worker himself may bring an action for the difference unpaid, if the instrument prescribes a higher rate. ${ }^{125}$ It seems that this remedy exists parallel to, or in lieu of, the Inspector's claim, but the relevant section of the Act does not refer to the Industrial Court. Where should proceedings be commenced: in the Industrial Court or in an ordinary court of law? The present author said elsewhere:126

The analogy of the Inspector's action under $\mathrm{s.} 158$ in accordance with breach of award proceedings would point to the first conclusion. Under the similar provisions of the repealed I.C. \& A. Act both the breach of award and the civil action could be commenced in a Magistrate's Court. The essential difference between these two actions

11: Id. 8. 149 .

118 Id. B. 148.

Iy Id. 8. 147; the limitation period in such actions is 12 months; Baillie and Co. Ltd. v. Reese (1960) 26 N.Z.L.R. 45; Strong v. L. Baya \& Co. Ltd. [1960] N.Z.L.R. 166 (S.C. \& C.A.).

120 ld. 8. 154.

121 Id. 8.155.

122 Id. 8. 158; the expression "award rates" includes also rates determined by collective agreements; Inspector of Awards v. Cleartite Plastics Ltd., re North Island Radio and Associated Electronics Award (1975) 75 B.A. 5385; Inspector of Awards v. Invercargill Licensing Trust, re N.Z. Licensed Hotels Employees Award (1975) 75 B.A. 7089; Inspector of Awards v. Kalaugher and Co. Ltd., re Wellington, etc., Building. Carriers, etc., Labourers and Other Workers Award (1976) 76 B.A. 19; Inspector of Awards v. Heylen Centre of Marketing Social and Opinion Research Ltd. (1976) 76 B.A. 85.

123 I.R. Act, 8. 169; see Sneddon v. Thomas Borthwick \& Sons (Australasia) Ltd. [1966] N.Z.L.R. 524 (S.C.).

124 It is of some interest that while the introductory words of 8 . 159 read "without affecting any other civil remedies", the word "civil" in 8.158 is omitted; see comments infra.

I2s I.R. Act, 8. 160.

126 Szakats, Introduction to the Law of Employment, para. 73; I.C. \& A. Act s8. 211 and $212 ;$ under 8.211 an action could be started either in the Magistrate's Court or in the Arbitration Court; in the first case appeal could be taken to the Arbitration Court but not to the Supreme Court: Hopper v. Lyall Bay Pictures Ltd. [1947] N.Z.L.R. 433; as to limitation the Limitation Act 1950; 8. 4(1)(a) and I.R. Act. ss. 158 and 160; the judicial decisions referred to are True v. Amalg. Collieries of W.A. Ltd. $[1940)$ A.C. 537 (P.C.) and Hill v. United Repairing Co. Led. (1946) N.Z.L.R. 585 (S.C.); Baille \& Co. Ltd. v. Reese (1906) 26 N.Z.L.R. 451; Wright v. N.Z. Woolpack and Textiles Ltd. (1947) G.L.R. 50. 
was that a special limitation period of two years applied to the breach of award claim, while the ordinary six years to the civil action. As a limitation period of two years applied in respect of the statutory claim, the distinction between an action "against the terms of the contract" and one "enforcing the terms of the contract" was most important. The period of limitation now is six years in both actions, and therefore the judicial decisions on the distinction have lost their relevance.

It would be fair to state that in respect of recovering award wages the relevant clauses of the instrument are not only enforceable by the employee as terms incorporated in his service contract, but also as terms independent of, or even going against, the contract, by his suing on the collective instrument itself. When the award sets down minima only, and the actually paid wages are higher, recovery is possible only under the contract. ${ }^{127}$

\section{THE FALLACY OF STATUS AS THE BASIS OF EMPLOYMENT}

\section{A. Recapitulation and Deductions}

The questions raised in the first part of this article relate to most complex issues and without a certain degree of generalization, perhaps oversimplification, no clear cut answers can be given. Some aspects, nevertheless, emerge as characterizing all collective instruments and their effects on the employment relationship in all the countries discussed. The following deductions may be stated in a centrifugal order.

(1) Collective instruments are enforceable through judicial proceedings, subject to certain prerequisites.

(2) Although the relevant terms are to be incorporated in the individual service contract, employees in some cases may seek direct enforcement; conversely the collective instrument may be directly enforced against them.

(3) There is very little room for workers to contract out of the terms superimposed by the collective instrument.

(4) Consequently individual bargaining and contractual freedom, especially for workers, has diminished almost to the point of disappearance.

(5) As a final result the collective instrument by prescribing wages and determining conditions of work for groups or classes of workers creates a status for all members of such groups or classes, and upon becoming a member the worker will be subject to collective rules.

These propositions will now be critically examined to see whether or not they can be accepted in their face value as true statements.

\section{Proposition (1): Enforceability}

Proposition 1 is plain and the legal rules examined support it. Prerequisites for, and methods of, enforcement may show considerable differences, but in all cases the parties have some form of judicial remedy available. Thus, in Britain the parties' written express intention to make the collective agreement a legally enforceable contract is a necessary prerequisite to any judicial proceeding for breach. ${ }^{128}$ In the

${ }^{227}$ Collective rates prevail against any lesser amount in the service contract: I.R. Act ss. 213 and $231 ; B o a g$ v Ropers and Prestidge Ltd. [1970] N.Z.L.R. 261; deviation in favour of the employee normally is possible, but by virtue of the Wage Adjustment Regulations 1974 (and amendments) issued under the Economic Stabilization Act 1948 the rates set in the instrument can be increased only with the approval of the authority designated for this purpose.

1zu Supra, Part II.B. 
United States and in Canada federal courts have the power to execute arbitral awards made under the procedure prescribed in the collective agreement, or may at an earlier stage order that the parties arbitrate their dispute. ${ }^{129}$

One must bear in mind that the collective instruments analyzed are not necessarily collective agreements in the pure sense of freely negotiated bilateral settlements. An agreement may result from a tripartite process, namely conciliation, or the intervention of a third party can culminate in the superimposition of a quasi-judicial order. In the last case the collective instrument by virtue of its very character must be judicially enforceable. At that point the difference in this respect between order-instrument and agreement-instrument disappears. These comments apply particularly to Australia and New Zealand where enforcement is through quasi-criminal proceedings. It should be noted, however, that a breach of award in Canada also can give ground to criminal prosecution. ${ }^{130}$

The conclusion may be argued with some force that a collective instrument, including a collective agreement in the narrow sense, notwithstanding its enforceability, cannot necessarily be equated with a contract, as the remedies in most, though not all, cases differ from the normal common law ones. While the assertion has some validity, the contractual effects of collective instruments are undeniable. The second proposition will throw more light on that claim.

\section{Proposition (2): Incorporation and Direct Enforcement}

The second proposition touches on the thorny problem of the interrelationship between the collective instrument and the individual employment contract. There can be no doubt that the provisions relating to wages and conditions of work, through the "Code effect", will form part of the contract of service by tacit or express incorporation, and that breach of such a contract is redressable in the normal manner independently of the collective instrument.

In certain circumstances, nevertheless, secondary parties, individual workers, may be in the same position as the primary parties, and they can seek direct enforcement through the collective instrument without a civil action on their contracts. Thus in Canada when enforcing a grievance arbitration award, the Court in the same proceedings can grant damages to the employee or employees affected. ${ }^{131}$ In Australia and in New Zealand outstanding wages may be directly recovered under the collective instrument. Furthermore, individual workers themselves may start an action, or can be liable for penalty in respect of a breach of award. Workers in these countries are expressly made parties to awards and collective agreements ${ }^{132}$ by virtue of the relevant statutory provisions. ${ }^{133}$

A nebulous area between collective and individual agreements is that of the peace obligation, the no-strike clauses. In Britain it is specially provided that provisions in a collective agreement prohibiting or

\footnotetext{
129 Supra, Part II.C and D.

130 Supra, Part II.E and Part III; as to Canada see n. 63, supra: "award". of course, in the Canadian context is not the collective instrument itself, as in Australia and New Zealand, but the decision of the arbitrator made in a concrete grievance.

131 Supre, n. 62.

132 In Australia called "industrial agreement".

133 Supra, Part II.E and Part III.
} 
restricting the right of workers to engage in a strike action shall form part of the employment contract only if certain pre-conditions are satisfied. As a result such clauses are enforceable against the union but not against the workers themselves, despite agreement with the employer to the contrary..$^{134}$ On the other hand, in the United States the no-strike clause is incorporated in the employment contract. Judicial extension has even broadened the peace obligation to agreements where merely the duty to arbitrate differences was expressed. The transposition of such "no-strike clause by implication" into the service contract has been criticized as loss of contractual freedom not only by the workers, but by the union itself. ${ }^{135}$ An implied "no-strike" promise, though it is an imposed prohibition to strike means that participation in a direct action by any worker would be in breach of his contract. This view is exactly opposite to the English solution which intends to safeguard the individual worker's right to strike.

In Australia bans clauses similarly affect the workers' rights in performing and accepting work, and, subject to the special enforcement procedure, penalties may be imposed on organizations and persons for contravening such clauses. ${ }^{136}$ In New Zealand statute prohibits parties to a dispute of interest, while it is before a conciliation council or the Industrial Commission, to engage in a direct action. The provision specially includes the words "nor the workers affected by [the dispute]", and adds that "the relationship of employer and employee shall continue uninterrupted". ${ }^{137}$ The collective regulatory norms and the service contract in this respect considerably overlap, and it is difficult to decide whether striking workers would breach a collective instrument, a statutory prohibition or their contract of employment. ${ }^{138}$

\section{Proposition (3): Superimposed Terms}

If the above statements are correct, then workers must accept the employment contract on the terms as prescribed in the collective instrument. Distinction should be made, however, whether the instrument lays down actual terms or merely minima. In the latter case deviation in favour of the worker is permitted. ${ }^{139}$ In addition, there are certain peripheral areas of the employment relationship usually not referred to in collective instruments to which common law implied terms still apply: such as personal service, duty of care and fidelity. Implied terms can always be negatived or modified by express ones.

Another aspect of Proposition (3) relates to the necessity of clearly defining organizations and persons bound by the collective instrument. It may refer to a single plant, or a specified industry in one geographical area, or it may be nationwide in that particular industry. Further, as far as workers are concerned, besides members of the union who are original parties, it normally extends to all employees working on jobs as identified and defined therein. In Britain this coverage is achieved by

\footnotetext{
1.4 Trade Union and Labour Relations Act 1974, s. 18(4); supra, Part II.B.

i3s See Local 174, Teamsters v. Lucas Flour, supra, n. 46.

${ }_{136}$ The Conciliation and Arbitration Act (Commonwealth) 1904-1976, 8. 33; supra, n. 87.

137 I.R. Act, 8. 81.

138 The question whether a strike terminates or merely suspends the employment contract is still argued; see Morgan v. Fry [1968] 2 Q.B. 710; supra, n. 29.

${ }^{135}$ Subject to anti-inflationary measures prohibiting payment of higher wages, e.g. the Wage Adjustment Regulations 1974 in New Zealand, (S.R. 1974/143 and its Amendments; at the time of writing there have been ten Amendments).
} 
the designation of bargaining units, ${ }^{140}$ in the United States ${ }^{141}$ and Canada ${ }^{142}$ by the recognition of bargaining representatives as exclusive bargaining agents for all workers actually employed or who may be employed in the future. In Australia the same purpose is achieved by the power of declaring a federal award to be a "common rule" in a specified industry, while a state award prima facie has this general applicability, subject to possible exemptions. ${ }^{143}$ Similarly in New Zealand awards and conciliated collective agreements have an extended binding force with respect to a particular industry, again subject to exemptions, but a voluntary collective agreement is restricted to the original and joining parties. ${ }^{144}$

Persons and also organizations not represented by the bargaining agency, or not within the ambit of the parties as designated by collective instruments in light of the relevant statutory provisions, or specially exempted and not covered by any other collective instrument, naturally can make their own contractual terms.

\section{Proposition (4): Contractual Freedom Curtailed}

Comparatively few employees can rely on their own personal bargaining power. This select circle includes top executives, outstanding scientists, famous theatrical personalities and some others in an equivalent position, but ordinary workers can conduct their individual bargaining only to a limited extent, and within the framework of the applicable collective instrument. Thus, where the instrument sets out several groups of workers with different designations and the groups are subdivided into grades and scales carrying a range of wage rates, a considerable measure of personal bargaining may be required to secure the appropriate group and the desired pay scale. Again, where the rates of pay and other conditions merely prescribe minima, higher rates and better conditions may be achieved by individual negotiations. ${ }^{145}$ Similarly, the common law implied terms referred to above can also be altered by express agreement.

Contractual freedom, considering all these possibilities, therefore, still exists, but, it must be admitted, with many restrictions. The strongest restriction is factual: although bargaining can be resorted to in theory whether or not in fact the worker has the necessary ability to gain the best conditions remains an open question. Actual service contracts indicate that in most cases, though not all, the worker accepts the minima, and does not query any conditions. It can be asserted that his freedom of contract is reduced to the choice between taking a job or rejecting it.

\section{Proposition (5): Not Status But Still Contract}

Is it true that employment has ceased to be a contractual relationship and has become a matter of status? The argument in the affirmative claims that the worker by the very fact of accepting employment under

180 Code of Practice, cls. 74-81; this Code was made under the now repealed Industrial Relations Act 1971, but the Trade Union and Labour Relations Act 1974, 8. 1(2)(a) expressly re-enacted it.

111 Taft-Hartley Act, s. 9; see Agreement between American Can Company and United Steelworkers, Feb. 15. 1974. Art. 3.1.

142 Code of Labour, s8. 107, 124-136.

1..1 Supra, Part II.E.

i14 Supra, Part III.

ins See e.g. American Can Co. and United Steelworkers Agreement, Art. 7: Nissen Datsun Manufacturing Ltd. Auckland Assembly Place Employees Coll. Agr. (Comp.) (1976) 76 B.A. 3415, cls. 5 and 7: Types of Salary Structures in Prices and Income Board Report, H.M.S.O. Cmnd. 4187 (1969) at 9-37. 
the superimposed regulatory terms joins a specific group of persons defined in the collective instrument, and all his rights and duties derive from his position in that group. Against this stands the assertion that the right to "take it or leave it" still preserves the worker's fundamental freedom "to choose for himself whom he would serve". ${ }^{146}$ Likewise, he may terminate his service at will upon giving the required notice.

At this juncture it seems necessary to clarify the meaning of status. Sir Henry Maine thought of it as "the sum total of the powers and disabilities, the rights and obligations, which society confers or imposes upon individuals irrespective of their own volition".147 In the words of Professor Graveson "a characteristic feature of the true status is its legally imposed condition which cannot be got rid of at the mere will of the parties without the interposition of some organ of the State, administrative, legislative or judicial". ${ }^{148} \mathrm{~A}$ fuller definition gives the meaning as follows: 149

[Status is] a special condition of a continuous and institutional nature differing from the legal position of the normal person, which is conferred by law and not purely by the act of parties, whenever a person occupies a position of which the creation, continuance or relinquishment and the incidents are a matter of sufficient social or public concern.

All these definitions emphasize the absence of volition not only in creating the "special condition", but also in relinquishing it. Where the individual has the legal power to decide, either unilaterally or in agreement with another party, without the interposition of a state organ, on the membership of the group to which the rights and obligations attach, there cannot be status in the true sense. The freedom of the worker to take and to quit a job thus should be a sufficient criterion to negative the contention that status has replaced contract as the basis of the employment relationship.

Contrariwise, the closed society of the middle ages gave no, or very little, possibility of changing one's rights and obligations arising from the status of being a serf, a villain or a labourer. ${ }^{150}$ Trades provided limited opportunities for advancement from apprentices through the stage of being a journeyman to the status of master, but only within the rigid structure of the guild system, upon strict compliance with severe tests and after undergoing solemn initiation rites. ${ }^{151}$ The incidents of belonging to a guild were considered to be matters of sufficient public concern. Guilds in the medieval sense do not exist any more. Trade unions which most workers join fulfil entirely different functions, and although membership in closed shop situations may be a prerequisite for obtaining and retaining work, ${ }^{152}$ the employee is at liberty to change not

\footnotetext{
146 Nokes v. Doncaster Amalgamated Collieries Ltd. [1940] A.C. 1014 at 1026 (H.L.), per Lord Atkin.

147 As pointed out by Sir Frederick Pollock in his comments to Maine, Ancient Law, chap. V. (1917 edition) referred to by Kahn.Freund, A Note on Status and Contract in British Labour Law (1967) 30 M.L.R. 635 at 636.

14* R. H. Graveson, Status in the Common Law, (London 1953) 48; see also E. H. White, The Modern Concept of Status, (1969) 7 Am. Business L.J. 175.

idy Id., Graveson at 2.

isu Statute of Labourers 1351 was passed to pressure the status of workers, when as a result of the plague labour became scarce; see B. W. Putnam, The Enforcement of the Statute of Labourers During the First Decade After the Black Death 1349-1359, (New York, 1908).

151 See Max Weber, General Economic History (Collier, New York 1961, transl. F. H. Knight) ch. 9 and 10; also M. Rehbinder, Status, Contract, and the Welfare State (1971) 23 Stanford L.R. 941 at 944.

152 At this point it should be made clear that the reference to membership of a group does not mean membership of a trade union but simply belonging to the class of workers covered by the industrial instrument, though the two in case of closed shop coincides; see Szakats, Compulsory Unionism: A Strength or Weakness (1972) 10 Alta. L.R. 313; F. J. L. Young, Union Membership, (Ind. Rel. Centre, Victoria Univ., Wellington, 1976).
} 
only his job but also the industry and the locality in which he wishes to be employed; as a consequence he may transfer his membership to another union.

The circumstance that the essential terms of the service contract are predetermined by the collective instrument does not affect its basic contractual character. The collective agreement, even though it may be legally enforceable as a contract, does not in itself create the actual employment relationship between the employer and the worker without their further acts of juristic significance. Such acts can be a formal agreement or an exchange of letters, but in industrial situations most frequently the service relationship is entered into by words or simply by conduct. When several labourers apply for a job, the foreman's pointing his finger at one of them and the answering nod sufficiently indicate the parties' intention to enter into a contract. 153 They need not necessarily discuss its detailed terms, as it is tacitly understood that those of the collective instrument will apply.

At this juncture some points in favour of the status theory should be mentioned. As the collective instrument is not always a collective agreement in the true sense but a decision of legislative character in judicial form, there could not be contract even between the primary parties. The superimposed collective terms merely represent state regulation. This contention appears to be reinforced by the fact that mandatory legislative rules of social and protective character play a substantial part in shaping the content of the employment relationship. Duties imposed by factory, safety and health statutes and regulations are binding on every person by force of the legislation alone. Employers and employees must observe them but so should visitors, invitees and everybody, irrespective of any contract. Coupled with the effect of the collective instrument, as a result of state interference employment obviously has become a matter of sufficient social and public concern, and it shows almost all the features of status, save of creating and relinquishing it. The argument concludes with the assertive question: do not the characteristics of status outweigh those of the contract?

\section{B. Conclusion: Contract Transferred by Mandatory Norms}

The answer must be firmly in the negative. The creation of the service contract by the will of the parties is a paramount factor which should not be confused with, and overshadowed by, the contents of the contract. There is nothing contradictory in entering into a contract with terms predetermined by a collective instrument and ultimately by law. Certain statutory norms have a dual character. thus, factory legislation binds the employer as occupier of the factory in any case, but in the employment relationship the norms will be incorporated in the contract as statutorily imposed terms. ${ }^{154}$ Professor Kahn-Freund with reference to Maine and Dicey aptly described the nature of employment as follows: ${ }^{155}$

[A] legal relation based on agreement but regulated by law, in the sense that its existence and its termination depend[s] on the volition of the parties, but its substance [is] determined by legal norms withdraw from the parties' contractual freedom.

153 See Sir Frank Tillyard, The Worker and the State, 3rd ed. (London, 1948) 4; Szakats, Introduction to the Law of Employment, para. 20.

154 Szakats, supra, n. 153, paras. 3, 20 and 44.

13s Kahn.Freund, supra, n. 147 at 640, see also W. Friedmann, Legal Theory, 5th ed. (London, 1967), 220; manpower planning with compulsory direction of labour might erode, and during wartime have eroded, the right of free choice, but in peace conditions in a democratic society such measures would be unacceptable; supra, n. 32 
The reference is to Dicey's statements that "the rights of workmen in regard to compensation for accidents have become a matter not of contract, but of status".156 If quoted out of context, and without the qualifying expression "in regard to compensation for accidents", the words of Dicey may be used as an argument for the reversal of Maine's characterization of "the movement of progressive societies ... from status to contract". ${ }^{157}$ The reversal, however, does not seem to eventuate in the context of employment, as "the law operates upon an existing contractual relation, but it moulds this relation through mandatory norms which cannot be contracted out to the detriment of the weaker party"..158

If the mere fact of mandatory legislation prescribing certain terms which must form part of a contract, in contradistinction to being merely, when lacking the parties' express agreement results in status, then standardized contracts, contracts d'adhesion, would create many strange categories of status: railway passenger, hire-purchaser, to mention only the most obvious ones. Nobody could deny that the basis of these relations is contractual.

Social legislation, nevertheless, has conferred on certain categories of people rights and obligations of a special nature which are not dependent on contract. Accident compensation in New Zealand, a form of social insurance, with some exceptions covers all members of the community, though different rules apply to earners and non-earners. ${ }^{159}$ In certain circumstances lack of contract may create a status. To be an employee means working under a contract. To be an unemployment beneficiary is a matter of status. 160

Freedom of contract has certainly been lost to some extent as a result of social control through mandatory protective legislation. It must not be forgotten, nevertheless, that despite the much praised political egalitarianism of the nineteenth century, gross economic inequality completely abrogated real freedom of contract and in the view of John Stuart Mill it became "but another name for freedom of coercion".161 Collective instruments purport to preserve the freedom of choice and at the same time to secure satisfactory working conditions in advance.

\footnotetext{
156 A. V. Dicey, Law and Public Opinion in England During the Nineteenth Century, (London, 1962$) 284$.

15: Maine, Ancient Law, (Everyman's London, 1960) 100.

13א Kahn-Freund, supra, n. 147 at 640; see also G. W. Brooks, Stability Versus Employee Free Choice, (1976) 61 Cornell L.R. 344.

1:5 Accident Compensation Act 1972 (N.Z.); see Szakats, Community Responsibility for Accident Injuries: the New Zealand Compansation Act, (1973) 8 U.B.C.L.R. 1; and Szakats, Introduction, supra, n. 153, ch. 22.

14t1) Social Security Act 1964 (N.Z.), 8. 58.60; see Szakats, supra, n. 153, para. 159.

Iii J. S. Mill, Principles of Political Economy, (with Introduction by W. J. Ashley, London, 1909) ch. V, XI; M. Ginsberg, On Justice in Society (Pelican 1065) 148 and ch. VIII.
} 